\title{
Structural and Ultrastructural Aspects of Folliculogenesis in Didelphis albiventris, the South-American Opossum
}

\author{
Aspectos Estructurales y Ultraestructurales de la Foliculogénesis \\ de Didelphis albiventris, la Zarigüeña Sudamericana
}

"Maria Dalva Cesario \& **Selma M. Michelin Matheus

\begin{abstract}
CESARIO, M. D. \& MATHEUS, S. M. M. Structural and ultrastructural aspects of folliculogenesis in Didelphis albiventris, the SouthAmerican opossum. Int. J. Morphol., 26(1):113-120, 2008.

SUMMARY: The ovarian histology, the structural and the ultrastructural characteristics of the folliculogenesis in Didelphis albiventris were described in detail. Recent studies suggest that methatherian mammals have unusual reproductive cycle but there are few informations regarding the marsupials reproductive life. Despite of the opossum folliculogenesis pattern resembles methatherian and eutherian pattern in many aspects, the analysis shows some peculiar features of the oocyte structure and ultrastructure that make available new data on the reproductive biology of marsupials.
\end{abstract}

KEY WORDS: Folliculogenesis, Oocytes; Opossum; Marsupial.

\section{INTRODUCTION}

Marsupials differ from eutherian mammals in their anatomical and physiological reproductive aspects although Mackay et al. (2004) have studied the postnatal reproductive tract development and have found that the mesonephric and paramesonephric ducts differentiation takes place after gonadal differentiation, according to the normal eutherian pattern. The opossum is a polyoestrous seasonal breeder (Fleming, 1973) and is sexually mature when in its 6 or 8 month-old and the females have two years of reproductive life. According to Collins (1973), Didelphis in Brazil has its first litter in August and September.

Earlier studies on marsupial oogenesis had suggested that it follows the biphasic growth pattern, typical from eutherian mammals (Lintern-Moore et al., 1976; Lyne \& Hollis, 1983; Kress et al. 2001). Because of the unusual reproductive cycle among the marsupials, data regarding oocyte organelles and nucleus, polyovular follicles, oocyte development, folliculogenesis control, embryonic membranes and implantation have been published (Harrison \& Weir, 1977; Hughes, 1977). Lyne \& Hollis described the Graafian follicles in Isoodon macrourus and Perameles nasuta. The grown follicles are usually very large but the oocyte size does not increase concomitantly.
Among the marsupials, researches were undertaken in bandicoot ovary (Ullmann, 1979, 1981, 1989) and in Monodelphis opossum oocytes (Baggott et al., 1987, Mate et al., 1992). Oocytes maturation and in vitro fertilization studies in marsupials, especially Dasyuridae, were described by Selwood, (1982), Breed \& Leigh, (1990), Breed, (1996) and Hickford et al. (2001). Kress et al. described the oogenesis pattern in Sminthopsis macroura and found that the timetable of oogenesis is accelerated as in other marsupials showing relatively early female maturation.

The available literature suggests that researches have been developed related to eutherian mammals and few of them are related to methatherian ones (Wolgemuth et al., 1984). Especially in Didelphis albiventris, the SouthAmerican opossum, no description of the folliculogenesis pattern was found. The goal of this paper is the description of some structural and ultrastructural characteristics of the south-american opossum ovary, with special attention to the ovarian follicles. These findings may contribute to the better understanding of the folliculogenesis and the reproductive behavior of this animal.

\footnotetext{
* Departamento de Morfologia, Instituto de Biociências, UNESP, São Paulo, Campus de Botucatu, Brasil.

** Departamento de Anatomia, Instituto de Biociências, UNESP, São Paulo, Campus de Botucatu, Brasil.
} 


\section{MATERIAL AND METHOD}

Adult females specimens of 400-500g weight were trapped in Botucatu City, São Paulo State, Brazil (IBAMA license $\mathrm{N}^{\circ}$ 002252/97-24). The experiments were conducted in accordance with the ethical guidelines for animal use, determined by the Brazilian College of Animal Experimentation (COBEA). The animals were anaesthetized by ether inhalation and perfused by Karnovsky's solution (2\% glutaraldehyde - 4\% paraformaldehyde in Sorensen's phosphate buffer 0.1 M, pH 7.3); through the left ventricle. The ovaries were removed and fixed overnight in Karnovsky’s solution.

For light microscopy, tissues were prepared to embed in Historesin (Historesin Jung 70-2218-500), according to standard methods and semithin sections were cut on Leica mod. RM 2065 microtome. These sections were stained with haematoxilyn and eosin and viewed under Zeiss Axiophot microscope.

For TEM, tissues were fixed for 24 hours in Karnovsky's solution, washed in $0.1 \mathrm{M} \mathrm{pH} 7,3 \mathrm{PBS}$, post-fixed in $1 \%$ osmium tetroxide in PBS, for 2 hours, at the darkness, washed in distilled water (three changes of 5 minutes), stained in the block with $0.5 \%$ aqueous solution of uranyl acetate for 2 hours, dehydrated through a graded series of acetone, embedded in 1:1 Araldite - $100 \%$ acetone solution (12 hours) and embedded in Araldite. Ultrathin sections were double stained with uranyl acetate and lead citrate. The sections were examined and photographed under a PHILIPS EM 301.

\section{RESULTS}

The opossum has two ovaries located in the pelvis cavity and histologically they are covered by a cuboidal epithelium, which is squamous in some extension. Immediately underneath this epithelium there is the tunica albuginea of irregular dense connective tissue. Each ovary is divided in two regions: a well-developed cortical region of dense stromal tissue and an internal medullary region of connective tissue with many blood vessels. The ovarian follicles with the oocytes are lying in the cortical region. The histological limit between both regions can readily be seen as the cortex is mainly acidophilic and the medulla is eosinophilic (Fig. 1).
The primordial ovarian follicles are found near to the tunica albuginea (Fig 1). A single layer of flattened squamous follicular cells around the oocyte may distinguish them. Nuclei of these cells are flat in shape and mitochondria and ribosomes are spread throughout the cytoplasm. The quiescent oocyte is spherical or oval in shape and it has a large, round and eccentrically located nucleus with a conspicuous and single nucleolus (Figs. 2 and 3). Its envelope has many pores and it is commonly named germinal vesicle. The chromatin material, that is rich in euchromatin, proceeds to the terminal stage of the first meiotic prophase (diplothene stage). The oocyte cytoplasm contains numerous rounded mitochondria showing electron-dense matrix between the usual organelles, like Golgi complex and endoplasmic reticulum. Electron-dense and multivesicular bodies are also dispersed throughout the ooplasm (Fig. 4).

When the oocyte begins its growth phase, the single layer of follicular cells around it becomes cuboidal epithelial cells that form the primary follicle (Figs. 1 and 5). As the oocyte develops the mitochondria take the elongated profile and are grouped under the plasmalemma. Electron-lucent vesicular bodies are common components in the ooplasm. In addition, the oocyte begins to be surrounded by a translucent noncellular material, the zona pellucida. A space develops between the oocyte and the surrounding follicular epithelium into which irregularly shaped microvilli project from the oolema and from the neighboring follicular cells, over the whole surface of the oocyte (Figs. 8 and 9).

The follicular growth is characterized by a steady increase in the number of follicular cells and the granulosa becomes a two-layer follicular cells (Fig. 6) and later, a multilayered envelope of follicular cells. The granulosa, than, acquires a theca tissue with two thecal layers: theca interna, which is of dense connective tissue with several blood vessels and theca externa of connective tissue (Figs. 6, 7 and 8). Numerous lipid-like droplets are present in the cytoplasm (Figs. 6 and 7).

The Graafian follicle exhibits an incipient antrum at the late stage and as the antrum expands, the oocyte takes up an eccentric position surrounded by two or more granulosa cell layers, the corona radiata and the cumulus cells with dilated intercellular spaces (Figs 10, 12 and 13). The oocyte ooplasm becomes full of electron-lucent vesicular bodies and elongated mitochondria are grouped at the cortical region (Fig. 11). 

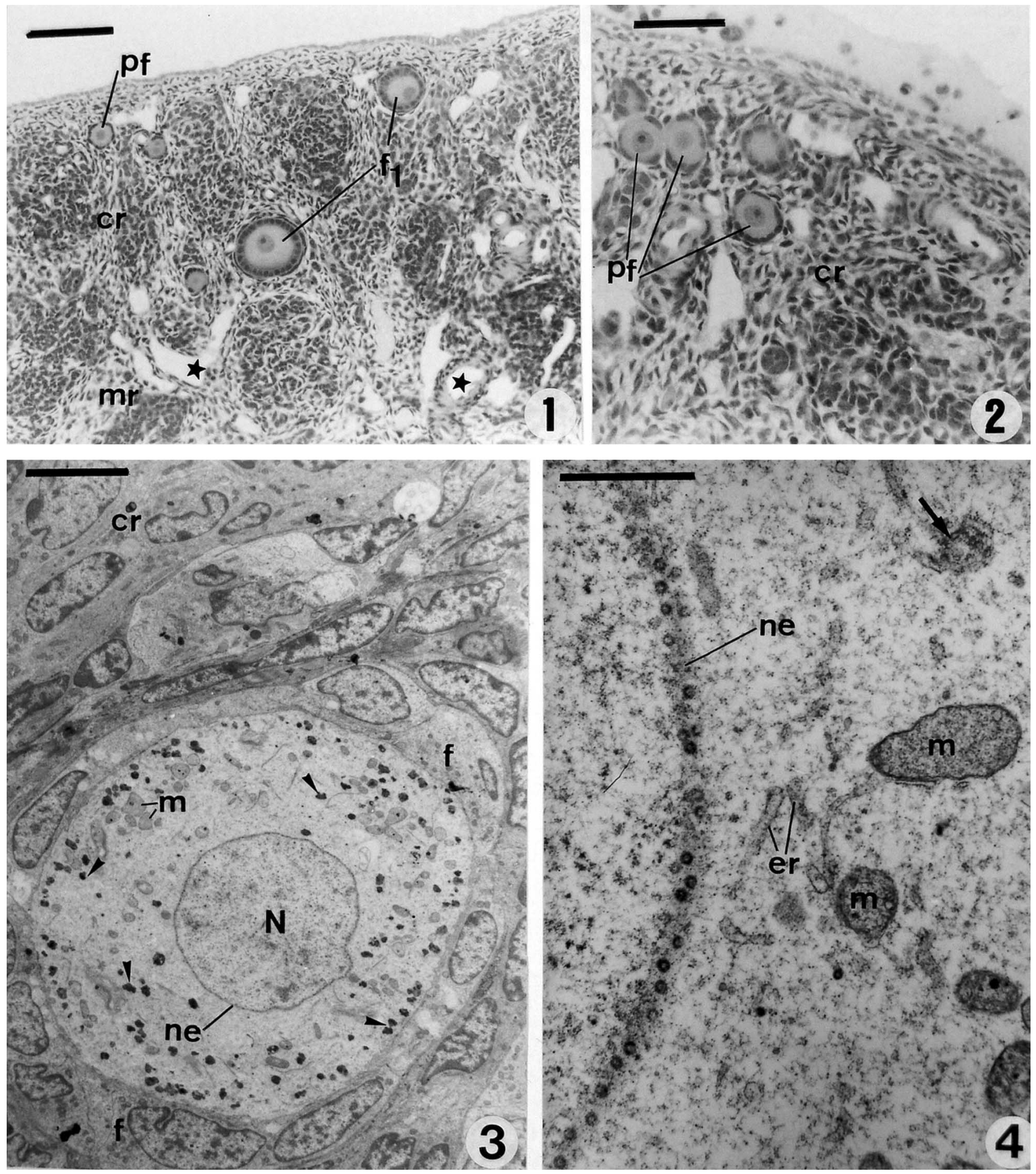

Fig. 1. Semithin section through ovary showing the cortical (cr) and medullary (mr) regions. Primordial (pf) and primary (p1) follicles are

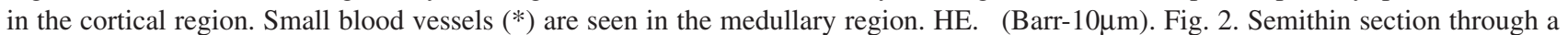
primordial follicle (pf) in the cortical region (cr). HE.(Barr-5 $\mu \mathrm{m})$. Fig. 3. Electron micrograph of a primordial follicle with flattened follicle cells (f) around the oocyte which cytoplasm is rich of mitochondria (m) and electron-dense bodies (arrowhead). Nucleus (N); nuclear envelope (ne) and cortical region (cr). (Barr-5 $\mu \mathrm{m})$. Fig. 4. Detail of primordial follicle nuclear envelope (ne) in which pores can be seen. Mitochondria (m); endoplasmic reticulum (er) and multivesicular bodies (arrow). (Barr- $1 \mu \mathrm{mm})$. 

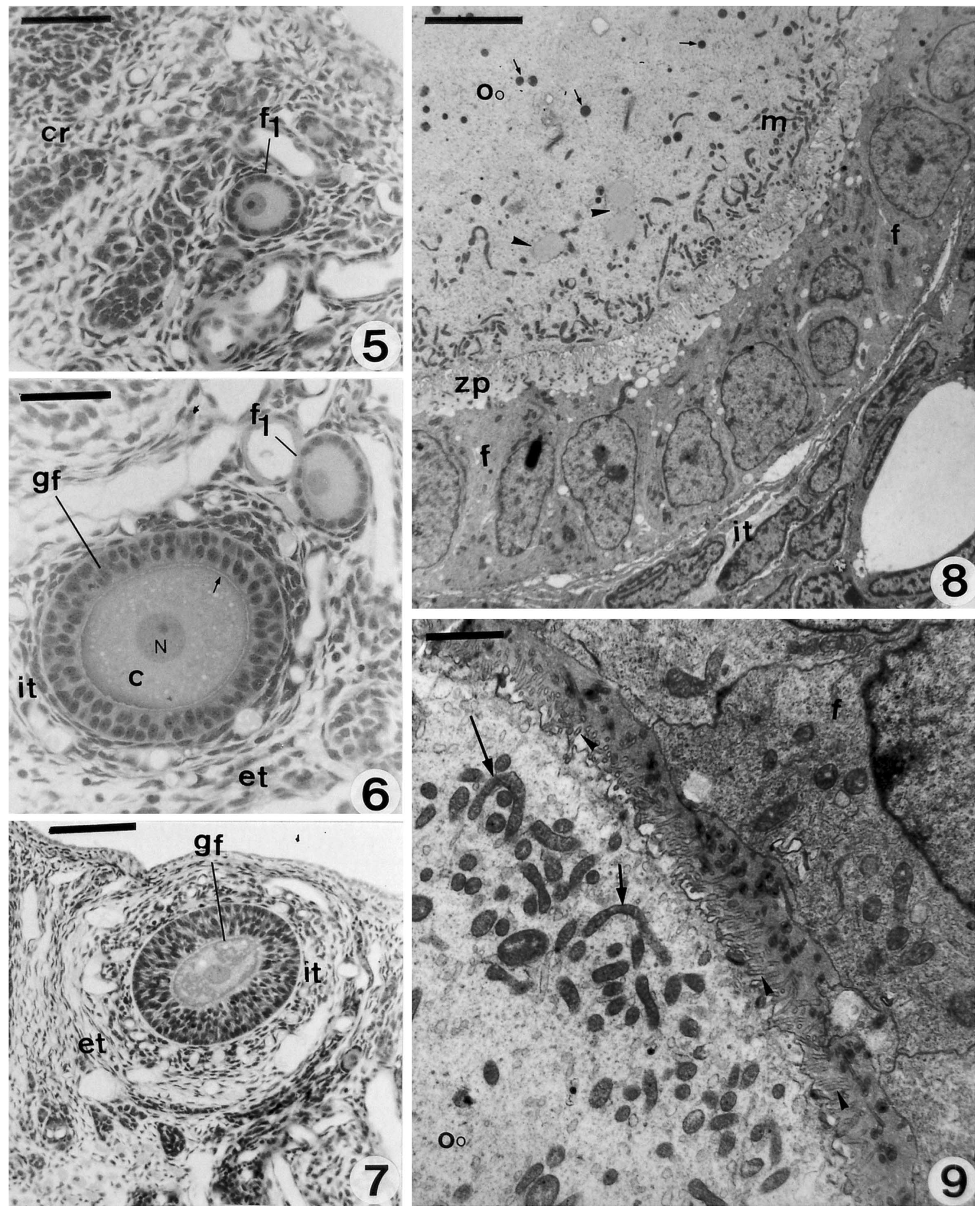

Fig. 5. Semithin section through cortical region of ovary showing a primary follicle (f1). HE (Barr-5 $\mu \mathrm{m})$. Fig. 6. Semithin section through cortical region of ovary showing a primary follicle (f1) and an early growing follicle (gf) surrounding by the theca interna (it) and externa (et). Its cytoplasm (c) shows many vesicles, nucleus with nucleolus $(\mathrm{N})$ and the zona pellucida (arrow). HE (Barr-5 $\mu \mathrm{m}$ ). Fig. 7. Semithin section showing a late growing follicle (gf) surrounding

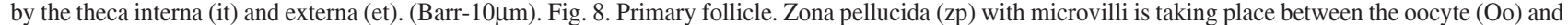
the cubic follicle cells (f). Elongated mitochondria (m), lipid-like droples (arrowhead) and electron-dense bodies (arrow) are observed in the cytoplasm of oocyte. Theca interna (it). (Barr-5 $\mu \mathrm{m}$ ). Fig. 9. Cortical cytoplasm area with elongated mitochondria (arrows) surrounding by the zona pellucida (zp) with microvilli (arrowheads) and follicular cells (f) of a growing follicle. (Barr-1 $\mu \mathrm{m})$. 

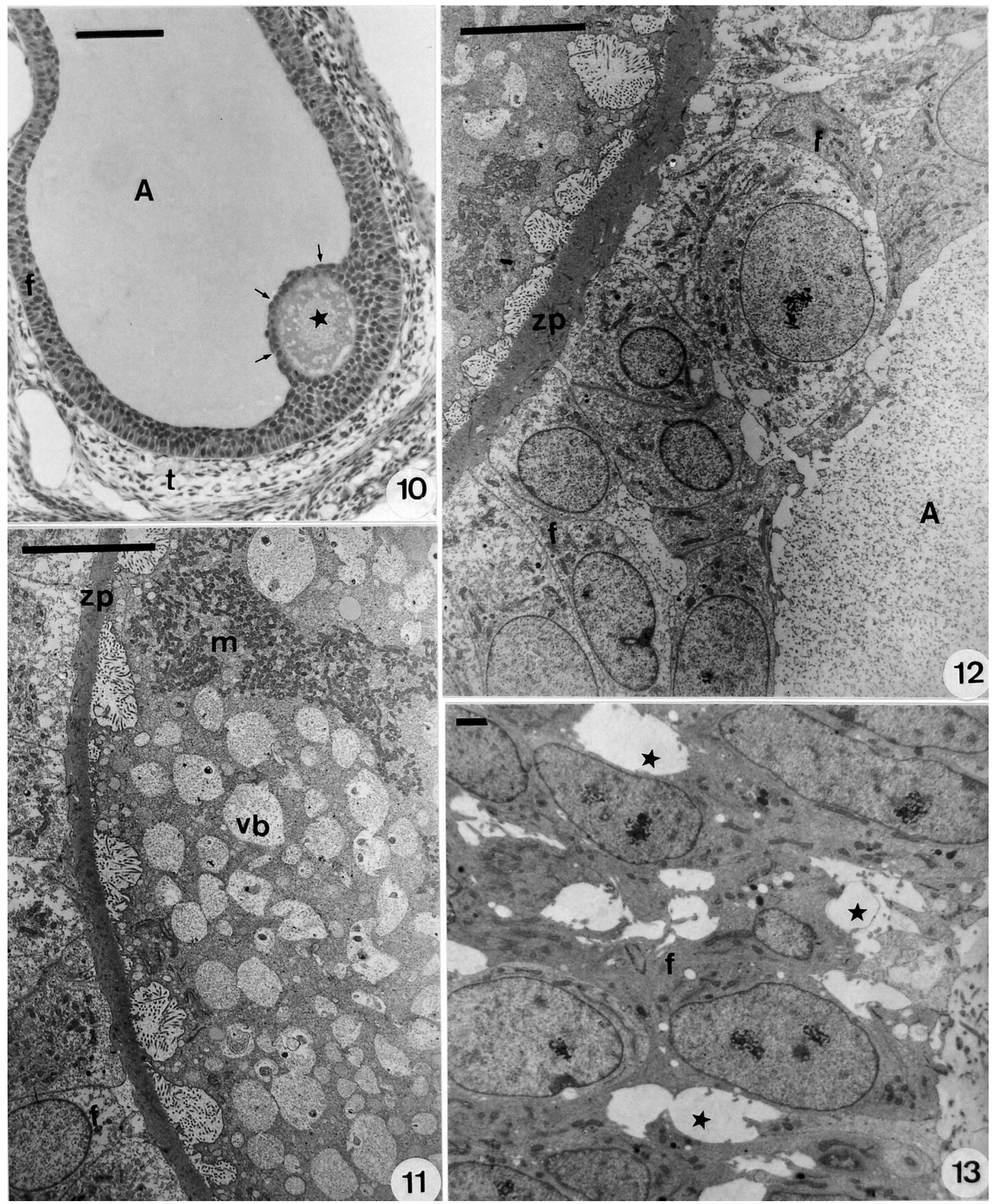

Fig. 10. Semithin section of a Graafian follicle showing the oocyte cytoplasm $(*)$ with the corona radiata cells (arrows) around and a large

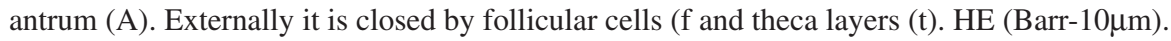

Fig. 11. Graafian follicle. Mitochondria (m) are grouped in the cortical cytoplasm. Many electron-lucent vesicular bodies (vb) are spread in the cytoplasm. The follicular cells (f) are around the zona pellucida (zp) and the oocyte. (Barr-10 $\mu \mathrm{m})$.

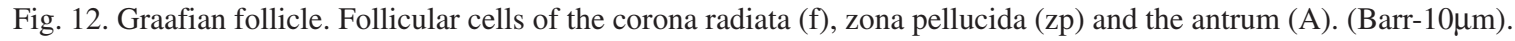

Fig. 13. Follicular cells (f) from Graafian follicle showing many spaces $(H)$ among them. (Barr-1 $1 \mu \mathrm{m})$. 


\section{DISCUSSION}

Light and electron-microscopic studies provided strong evidence that the ovarian histology and the folliculogenesis in opossum resemble that of the eutherian pattern in some respects. There is a well-developed cortex of dense stromal tissue covered peripherally by a cuboidal germinal epithelium, which is squamous in some extensions and a medullary region with connective tissue and many blood vessels. Among the methatheria Lyne \& Hollis have observed the same structure in Isoodon macrourus and Perameles nasuta.

The ovarian follicles with the oocytes are in the cortical region and primordial follicles that have a monolayer of flattened follicular cells around the oocyte can be easily identified. Our data about oocytes ooplasm and nuclei are in agreement with Ullmann (1979) for bandicoot; Frankenberg et al. (1996) for brushtail possum; Lucci et al. (1999) for goat and Browder (1985) for mammals in general.

Numerous pore complexes perforate the nuclear envelope of the opossum oocyte. According to Browder these pore complexes are ubiquitous structures found in all eukaryotic cells and have a highly regular architecture. They are important gateways in the macromolecules translocation.

Hyttel et al. (1997), Lucci et al. and Kress et al. found that the communication between the oocyte and the granulosa cells is apparently mediated through an endocytotic pathway as signaled by the abundant coated pits and vesicles present in the oocyte. We have found some vesicles in the analyzed oocytes but they are not in the same pattern described by these authors. The electron-lucent vesicular bodies observed in the ooplasm as the oocytes increase, are probably yolk spheres, protein vesicles, lipid and carbohydrate, the egg nutritional substances constituents. The same structural pattern was found in dogs and pigs oocytes and in preimplantation embryos (Landin e Alvareng \& Bicudo, 1997). The authors discuss that they are essential during the preimplantation period as a nutritional source for these embryos. The similar pattern of oocyte ooplasm opossum leads us to suppose that in opossum embryos the same nutritional source is required but a further study about the nature of this droplets must be conducted.

Electron-dense bodies are usually dispersed throughout the ooplasm and they could be RNA and proteins, (secreted granulations). During oocytes growth the rounded mitochondria became elongated and gradually underwent a peripheral dislocation. Cui et al. (2005) studied oogenesis in the common brushtail possum and found their oocytes with a cytoplasm rich in mitochondria. Hyttel et al. observed the same change in cattle and Lucci et al., in goat. Frankenberg \& Selwood (2001) found that the brushtail possum ova are slightly larger on average than those of eutherian animals and the same electron-lucent vesicles and electron-dense granular bodies were found in growing opossum oocytes. Harder \& Jackson (2003) found in Monodelphis domestica, that the antral follicles diameters were $393 \pm 4 \mathrm{~mm}$.

Previous studies indicate that the zona pellucida consists of glycoproteins synthesized by the oocyte and the granulosa cells during the onset of growth phase and the $\mathrm{ZP}$ glycoproteins appear only after multiple layers of these cells are present (Selwood, 2000). Jewgenow \& Rudolph (2001) concluded that the zona pellucida in cats is exclusively produced by granulosa cells and its synthesis takes place at every stage of follicular development. Our results demonstrated that the opossum zona pellucida construction occurs in the same way as in those animals. Sharman, (1961) found that marsupial's follicular envelope is typically thinner than that of other mammals. According to Hughes the zona pellucida, a protein- and carbohydrate-rich viteline coat, is of ovarian cell origin and is fully formed at the ovulation time.

Our results provided the first description of some structural and ultrastructural features of folliculogenesis in Didelphis albiventris, the South-American opossum. This description makes available data that are fundamental to the studies of its reproductive biology.

ACKNOWLEDGEMENTS. We would like to thank the Centro de Microscopia Eletrônica, IB, UNESP, Botucatu, SP, Brasil, for the facilities in use.

CESARIO, M. D. \& MATHEUS, S. M. M. Aspectos estructurales y ultraestructurales de la foliculogénesis de Didelphis albiventris, la zarigüeña sudamericana. Int. J. Morphol., 26(1):113-120, 2008.

RESUMEN: Fueron descritas con detalles la histología ovárica, las características estructurales y ultra-estructurales de la foliculogénesis del Didelphis albiventris. Estudios recientes sugieren que mamíferos metaterios tienen un ciclo reproductivo inusual, pero existen pocas informaciones en relación a la vida reproductiva de los marsupiales. A pesar de que el modelo de foliculogénesis de la zarigüeya se parece al modelo metaterio y euterio en muchos aspectos, el análisis muestra algunos rasgos peculiares de las estructura y ultra-estructura del oocito, que colocan a disposición nuevos datos en la biología reproductiva de los marsupiales.

PALABRAS CLAVE: Foliculogénesis; Oocitos; Zarigüeya; Marsupial. 


\section{REFERENCES}

Baggot, L.; Davis-Butler, M.S. \& Moore, H.D. M. Characterization of oestrus and timed collection of oocytes in grey short-tailed opossum, Monodelphis domestica. J. Reprod. Fert., 79: 105-14, 1987.

Breed, W. G. Egg maturation and fertilization in marsupials. Reprod, Fertil. \& Develop. 8(4):617-43,1996.

Breed, W. G. \& Leigh, C. M. Morphological changes in the oocyte and its surrounding vestments during in vivo fertilization in the Dasyurid Marsupial Sminthopsis crassicaudata. J. Morphol. 204:177-96, 1990.

Browder, L.W. Developmental Biology. A Comprehensive Synthesis. Oogenesis. $1^{\text {a }}$ ed. New York, Ed. Plenum Press, 1985. V. 1.

Collins, L. R. Monotremes and marsupials. A reference for zoological institutions. Washington, D.C., Smithson Inst. Press. 1973.

Cui, S.; Nikolovski, S.; Nanayakkara, K. \& Selwood, L. VAP1, with cystatin C motif, an oocyte protein encoded by a novel ovarian-specific gene during oogenesis in the common brushtail possum (Trichosurus vulpecula). Mol. Reprod., Dev. 71(1):19-28, 2005.

Fleming, T. H. The reproductive cycles of three species of opossums and other mammals in the Panama Canal Zone. J. Mamm., 54:439-55, 1973.

Frankenberg, S.; Newell, G. \& Selwood, L. A light microscopic study of oogenesis in the brushtail possum Trichosurus vulpecula. Reprod. Fertil. \& Develop., 8(4): 541-546, 1996.

Frankenberg, S. \& Selwood, L. Ultrastructure of oogenesis in the brushtail possum. Molecular Reproduction \& Development, 58(3):297-306, 2001.

Harder, J. D. \& Jackson, L. M. Male pheromone stimulates ovarian follicular development and body growth in juvenil female opossums (Monodelphis domestica). Reprod. Biol. Endocrinol., 1(1):21, 2003.

Harrison, R. J. \& Weir, B. J. Structure of mammalian ovary. In: Zuckerman, L. S., B. J. Weir, Eds. The ovary. $2^{\text {nd }}$ ed New York, Academic Press, 1977. V. 1. pp. 113-217.

Hickford, D. E.; Merry, N. E.; Johnson, M. H. \& Selwood,
L. Induced ovulation, mating sucess and embryonic development in the stripe-faced dunnart, Sminthopsis macroura. Reproduction, 122(5):777-83, 2001.

Hughes, R. L. Egg membranes and ovarian function during pregnancy in the monotremes and marsupials. In: Calaby, J. H., C. H. Tyndale-Biscoe, (ed). Reproduction and Evolution Autralian Academy of Sciences, Camberra, 1977. pp. 281-91

Hyttel, P.; Fair, T. H.; Callesen, T. \& Greve, T. Oocyte growth, capacitation and final maturation in cattle. Theriogenology, 47:23-32, 1997.

Jewgenow K. \& Rudolph, M. Timing and location of zona pellucida synthesis during oogenesis in domestic cats an ultrastructural immunohistological investigation. $J$. Reprod. \& Fert. 57 (Suppl):23-9, 2001.

Kress, A.; Merry, N. E. \& Selwood, L. Oogenesis in the marsupial stripe - faced dunnart, Sminthopsis macroura. Cells Tissues Organs., 168(3):188-202, 2001.

Landin e Alvarenga, F. C. \& Bicudo, S. D. Ultrastructural study of pre-implantation dog embryos. Braz. J. Morphol. Sci. 14(2):213-7, 1997.

Lintern-Moore, S.; Moore, G. P. M.; Tyndale-Biscoe, C. H. $\&$ Poole, W.E. The growth of the oocyte and follicle in the ovaries of monotremes and marsupials. Anat. Rec., 185: 325-32, 1976

Lucci, C. M.; Carvalho, F. C. A.; Silva, J. R. V.; Figueiredo J.R. \& Báo, S.N. Study of goat ovarian preantral follicles with light and transmission electron microscopy (TEM). Acta Microscópica. 8 (suppl. B oct.):295-6, 1999.

Lyne, A. G. \& Hollis, D. E. Observation in Graafian follicles and their oocytes during lactation and after removal of pouch young in the marsupials Isoodon macrourus and Perameles nasuta. Am. J. Anat., 166:41-61, 1983.

Mackay, S.; Xie, Q.; Ullmann, S. L.; Gilmore, D. P. \& Payne, A. P. Postnatal development of the reproductive system in the grey short-tailed opossum. Monodelphis domestica. Anat. Embryol. (Berl)., 208(2):121-33, 2004.

Mate, K. E.; Giles, I. \& Rodger, J. C. Evidence that cortical granule formation is a periovulatory event in marsupials. J. Reprod. Fert., 95:719-28,1992. 
Novak, R.M. Walker's Mammals of the World. (5 $5^{\text {th }}$ ed). London: The Johns Hopkins University Press, 1991. V. 1. Cap. Marsupialia, pp. 10-113.

Selwood, L. A review of maturation and fertilization in marsupials with special reference to the dasyurid: Antechinus stuartii. In Carnivorous Marsupials. Sydney: Ed M. Archer. Royal Zoological Society NSW, 1982. V. 1. pp 65-76,

Selwood, L. Marsupial egg and embryo coats. Cells Tissues Organs, 166(2): 208-19, 2000.

Sharman, G.B. The embryonic membranes and placentation in five genera of diprotodont marsupials. Proc. Zool. Soc. Lond., 137:197-220, 1961.

Ullmann, S. L. Observation on the primordial germ cells of bandicoots (Peramelidae, Marsupialia). J. Anat. 132(4):581-5, 1981.

Ullmann, S. L. Observation on the primordial oocyte of the bandicoot Isoodon macrourus (Peramelidae, Marsupialia). J. Anat., 128(3): 619-31, 1979.

Ullmann, S.L. Ovary development in bandicoots: sexual differentiation to follicle formation. J. Anat., 165:45-60, 1989.

Wolgemuth, D. J.; Celenza, J.; Bundman, D. S. \& Dunbar, B.S. Formation of the rabbit zona pellucida and its relationship to ovarian follicular development. Dev. Biol.106(1):1-14, 1984.
Correspondence to:

Dr. Maria Dalva Cesario

Departamento de Morfologia

Instituto de Biociências

Universidade Estadual Paulista - UNESP

CEP: $18618-000$

Botucatu - SP

BRASIL

Email: mcesario@ibb.unesp.br

Received: 14-08-2007

Accepted: 08-01-2008 